\title{
Betonarme Çerçevede Dolgu Duvarların Hasır Çelik Donatılı Sıva İle Güçlendirilmesi
}

\author{
Hamide TEKELI' ${ }^{* 1}$, Osman AKYÜREK ${ }^{1}$, Metin DENIZ ${ }^{1}$, Emircan HERSAT ${ }^{1}$, \\ Necmi KARA ${ }^{1}$, Uğur TOSUN ${ }^{1}$, Fatih KAYA ${ }^{1}$ \\ ${ }^{1}$ Süleyman Demirel Üniversitesi, Mühendislik Fakültesi, Inşaat Mühendisliği Bölümü, Isparta
}

\begin{abstract}
Özet
Literatürde güçlendirme için farklı yöntemler mevcuttur. Bu çalışma kapsamında "Dolgu duvarların hasır çelik donatılı özel sıva ile güçlendirilmesi" yöntemi incelenmiştir. Bu amaçla, 4 adet aynı yapısal özelliklere sahip betonarme çerçeve üretilmiştir. Bu numunelerden bir tanesi yalın halde bırakılırken, diğer üçünün açıklı̆ğ dolgu duvar ile örülmüş̧ür. Tuğla dolgu duvarlı betonarme çerçevelerden iki tanesi, duvar yüzeyine tek taraflı olarak uygulanan hasır donatılı sıva ile güçlendirilmiş̧ir. Güçclendirilen iki numunede ankraj aralığı ve işçiliği değiştirilmiştir. Elde edilen sonuçlardan yapılan güçlendirmenin elemanın yük taşıma kapasitesi yanında enerji tüketme kapasitesini de artırdığı görülmüştür. Yanal yük taşıma kapasitesi açısından dolgu duvarlı numunede $\% 120$, seyrek ankraj ile güçlendirmede $\% 160$ ve sık ankraj ile güçlendirmede $\% 180$ yalın numuneye göre artış sağlanmıştır. Ankraj işçiliği kötü olan numunede güçlendirme yüzeyinin deney sırasında dolgu duvardan ayrıldığı görülmüştür. Güçlendirmenin tek taraflı yapılması nedeniyle gü̈çlendirme uygulanmayan yüzeyde hasar $\mathrm{X}$ şeklinde ortaya çıkmıştır. Bu nedenle güçlendirmenin, duvarın tek tarafından ziyade her iki yüzünde de yapılmasının davranış açısından daha uygun olacağı düşünülmektedir.
\end{abstract}

Anahtar Kelimeler: Betonarme çerçeve, dolgu duvar, güçlendirme, hasır çelik

\section{Strengthening With Steel Wire Mesh of Infill Wall in RC Frames}

\begin{abstract}
There are the different methods used for strengthening in the literature. In this study, the method of strengthening with steel wire mesh of infill wall is examined. For this reason, four reinforced concrete frames are constructed with the same structural characteristics. While one of these samples is prepared without infilled wall (simple), the others are prepared as with infilled wall. The two samples with infill wall are strengthened with steel wire mesh. The spacing and workmanship of anchors are changed in the strengthened samples. The obtained results showed that energy assumption and lateral load capacities increased in strengthened samples. The lateral load capacities of sample with infilled wall and the strengthened samples with poor and good workmanship of anchors have increased by $120 \%, 160 \%$ and $180 \%$ compared to simple sample, respectively. It has been observed that the strengthening face split from the infill wall in the sample in which the workmanship of anchor is poor. Because the strengthening was applied in the single side, the infill wall in the other side cracked in $\mathrm{X}$ shape. So, the strengthening must be applied in the both sides rather than single side of infill wall.
\end{abstract}

Keywords: RC frame, infill wall, strengthening, steel wire mesh

\section{Giriş}

Türkiye, deprem riski açısından dünyanın en önde gelen ülkelerinden biridir. Ülkemizin yüz ölçümünün yaklaşık \% 42'si birinci derece deprem bölgesi üzerindedir. Depreme dayanıklı yap1 oluşturmayı amaçlayan deprem yönetmeliklerindeki şartların tam ve doğru olarak yerine getirilebilmesi için proje ve yapım aşamasında verilecek bir mühendislik hizmetinin yararı gayet açıktır. Ancak, ülkemizin önemli bir deprem kuşağında olmasının yanı sıra yapım kalitesinde ve

"Sorumlu Yazar: hamidetekeli@gmail.com 
kontrol mekanizmasında eksikliklerinin olduğu bilinmektedir. Dolayısıyla meydana gelebilecek depremlerde çok sayıda can kaybına ve büyük ekonomik kayıplara sebep olabilecek bir durumun ortaya çıkma ihtimali oldukça yüksektir. Son yıllarda meydana gelen Erzincan (1992), Dinar (1995), Adana-Ceyhan (1998), Kocaeli (1999), Bolu-Düzce (Kasım 1999), Afyon-Çay (2002) ve Van (2011) depremleri bu konuyu doğrular niteliktedir. Depremlerin oluşturacağı hasarları azaltmanın en etkin yolu ise depreme dayanıklı yapıların inşa edilmesidir. Ancak bu durum, yeni yapılacak olan binalar için bir tedbir olabilirse de daha önce yapılmış mevcut binalar için deprem güvenliklerinin kontrol edilmesi ve gerekli görülenlerin bir an önce güçlendirilmesinin gerekliliğini ortaya koymaktadır.

Güçlendirme tekniklerinin, yap1 performansına katkıları, sosyal olarak kabul edilebilir olmaları, ekonomik uygunlukları ve teknik olarak uygulanabilirlik kriterleri gözetilerek ilerleyen teknoloji ve malzeme bilgisi ışığında geliştirilmeleri ve yeni yöntemlerin oluşturulması gerekmektedir [1]. Farklı güçlendirme yöntemlerinin etkinliği üzerine pek çok ülkede olduğu gibi ülkemizde de deneysel ve analitik çalışmalar yapılmaktadır. Bu kapsamdaki çalışmaların bir kısmını betonarme çerçevelerin güçlendirilmesi konusu oluşturmaktadır. Bu çalışmaların bazılarında, dolgu duvarın CMG [2,3] ve FRP [4-8] gibi kompozitler, önretimli şerit beton paneller [9-11], boşluklu betonarme perde duvar [12] ve dış perde duvar [13-15] ilavesi ile güçlendirilmesinin etkinliği deneysel olarak incelenmiştir. Bunlara ilave olarak betonarme çerçevelerdeki dolgu duvarın çelik hasır donatılı sıva uygulaması ile güçlendirilmesi konusunda da literatüre önemli katkılar sağlanmıştır [1, 16-18]. Örneğin Acun ve Sucuoğlu [1] tarafından yapılan çalışmada kullanılan hasır donatı oranı ile yüzeye uygulanan sıva dayanımının, Özdemir [17] tarafından yapılan çalışmada ise çerçeveye yapılan ankraj aralığının, duvar düzlemine dik ankraj sayısının, sıva kalınlığının ve sıva kalitesinin değişiminin performansa katkısı araştırılmıştır. Acun ve Sucuoğlu [1] tarafından elde edilen sonuçlarda sıva dayanımı ve donatı oranı parametrelerinin artımına bağlı olarak test edilen elemanların rijitlik ve yatay yük taşıma kapasitelerinde belirgin iyileşmeler gözlendiği vurgulanırken, Özdemir [17] tarafindan yapılan çalışmada güçlendirme sıvasının dayanım ve kalınlığının artırılmasının rijitlik ve taşınan maksimum yükü fazla değiştirmediği ve çerçeve ankraj aralıklarının değişmesinin, yatay yük taşıma kapasitesi, rijitlik ve enerji yutma kapasitesinde ciddi bir farklılık göstermediği vurgulanmıştır.

Deprem Bölgelerinde Yapılacak Binalar Hakkında Yönetmelik 2007 (DBYBHY 2007)'nin [19] Ek-7F bölümünde dolgu duvarların güçlendirilmesi için farklı yöntemler verilmiştir. Çalışma kapsamında bu yöntemlerden "Dolgu duvarların hasır çelik donatılı özel sıva ile güçlendirilmesi" yöntemi ile güçlendirmenin etkinliği incelenmiştir. Bu yöntemin seçilmesinin amacı hasır donatı üzerine püskürtme beton ve kalıp hazırlığı yapılmasına gerek duymadan çok daha az bir işçilik ile güçlendirme işleminin yapılabilmesidir.

Bu amaçla, 4 adet tek katlı, tek açıklıklı ve 1/3 ölçekli aynı yapısal özelliklere sahip betonarme çerçeve üretilmiştir. Bu numunelerden bir tanesi yalın halde bırakılırken, diğer üçünün açıklığı dolgu duvar ile örülmüştür. Tuğla dolgu duvarlı betonarme çerçevelerden iki tanesi, duvar yüzeyine uygulanan hasır donatı ile güçlendirilmiştir. Güçlendirilen iki numunede ankraj aralığı ve işçiliği değiştirilmiştir. Böylece yapılan çalışma ile dolgu duvarlı yapıların davranışa etkisi, güçlendirme yönteminin etkinliği, uygulamada karşılaşılan detay ve işçilik farklılıklarının davranışa etkisi gibi farklı parametrelerin değerlendirilmesi sağlanmıştır.

\section{Materyal ve Yöntem}

\subsection{Deney Numunelerinin Hazırlanması Ve Güçlendirilmesi}

Hasır donatı ile güçlendirme işlemi uygulamasında genellikle hasır donatı üzerine püskürtme beton veya kalıp hazırlığı yapılarak beton dökümü gerçekleştirilmektedir. Bu uygulamalar oldukça 
zaman alıcı ve zahmetlidir. Bu nedenle çalışma kapsamında, kalıp veya püskürtme beton hazırlığına gerek kalmadan çok daha az bir işçilik ile güçlendirme işleminin yapılıp yapılamayacağı incelenmiştir.

Bu amaçla, öncelikle detayları Şekil 1'de görülen 4 adet tek katlı, tek açıklıklı ve 1/3 ölçekli betonarme çerçeve üretilmiştir. Bu numunelerden bir tanesi boş olarak bırakılmıştır. Diğer üçünde açıklı̆̆ın tamamı dolgu duvar ile örülmüştür. Tuğla dolgu duvarlı betonarme çerçevelerden iki tanesi, duvar yüzeyine uygulanan hasır donatı ile güçlendirilmiştir. Güçlendirilen iki numunede ankraj aralığ ve işçiliği değiştirilmiştir. Üretilen numunelere ait özellikler Tablo 1'de verilmiştir.
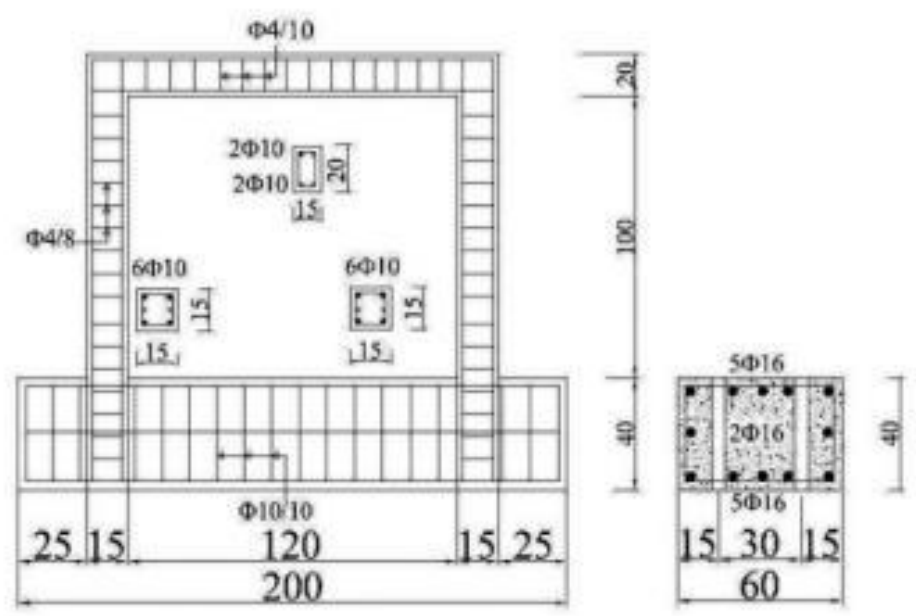

Şekil 1. Betonarme çerçeve numunesine ait donatı detayları

Tablo 1. Hazırlanan deney numunelerine ait özellikler

\begin{tabular}{|c|c|c|}
\hline Numune numarası & Çerçeve Özelliği & Dolgu duvarın yerleşimi \\
\hline N1 & Yalın referans çerçeve & \\
\hline $\mathrm{N} 2$ & Tam dolu dolgu duvarlı çerçeve & \\
\hline N3 & $\begin{array}{c}\text { Tam dolu dolgu duvarlı } \\
\text { çerçevenin hasır donatı ile } \\
\text { güçlendirilmesi } \\
\text { (seyrek ankraj) }\end{array}$ & \\
\hline N4 & $\begin{array}{l}\text { Tam dolu dolgu duvarlı } \\
\text { çerçevenin hasır donatı ile } \\
\text { güçlendirilmesi } \\
\text { (sık ankraj) }\end{array}$ & 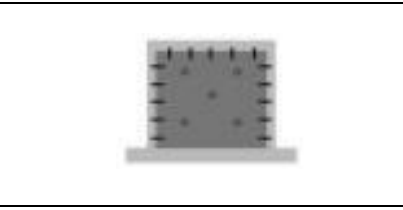 \\
\hline
\end{tabular}

Numunelerin daha hızlı ve kolay üretilebilmesi için, çelik saç kalıp kullanılmış ve numuneler yerde yatay olarak hazırlanmıştır. Numune temelinde hem çerçeveye paralel (yatay) hem de çerçeveye dik (düşey) yönde boşluklar bırakılmıştır. Yatay boşluklar deney numunesinin ara temel betonuna bağlantısının yapılması, düşey boşluklar ise numunenin taşınması işleminde kullanılmıştır. Numunenin üretiminde C20 sınıfı hazır beton ve S420 donatı sınıfı kullanılmıştır. Beton dökümü sırasında vibratör uygulaması ile betonun iyi bir şekilde sıkışması sağlanmıştır (Şekil 2). 


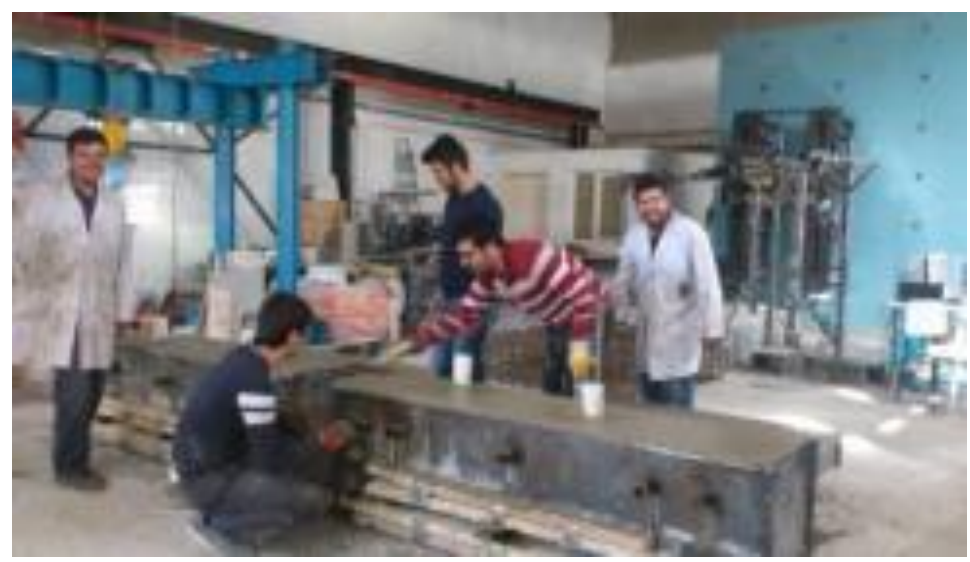

Şekil 2. Numune betonunun döküm aşaması

Tuğla duvar örüm işleminde kullanılan harç karışımı tüm numunelerde aynı oranlarda hazırlanmıştır. Duvar örümü şaşırtmalı örgü türünde yapılmıştır. En son sıraya tam sıkışmasının sağlanması için köpük sıkılmıştır (Şekil 3).
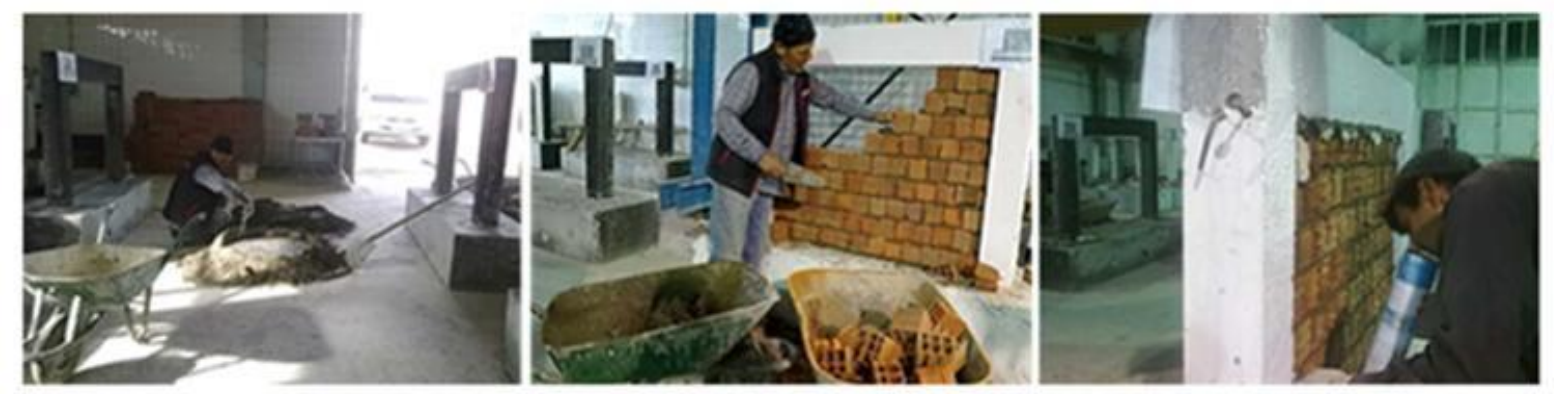

Şekil 3. Duvar örümü aşamaları

İkinci numunede dolgu duvar üzerine sıva uygulaması yapılmıştır. Üçüncü ve dördüncü numuneler ise dolgu duvar üzerine yerleştirilen hasır donatı ile güçlendirilmiştir. Güçlendirme sırasında her iki numune için Q100/100 hasır donatısı kullanılmıştır. Güçlendirilen iki numunede kolon, kiriş ve dolgu duvar üzerine yerleştirilecek ankraj çubuklarının mesafesi ve işçilikte gösterilen özen değiştirilmiştir. Güçlendirme işlemi duvarın sadece tek yüzeyinde uygulanmıştır. DBYBHY 2007 'de [19] ankraj çubuklarının en az çapı $(\phi) 12 \mathrm{~mm}$, aralığı (s) $300 \mathrm{~mm}$ ve derinliği (l) ise $12 \phi$ olarak verilmiştir. Ayrıca yönetmeliğe göre donatılı sıva ile mevcut dolgu duvarın birlikte çalışmasını sağlamak için duvar düzlemine dik yönde, her bir metrekare duvar alanında dört adet gövde ankrajının yapılması öngörülmüştür. Tüm ankraj çubuklarının epoksi esaslı malzeme ile ekilmesi ve uçlarının L şeklinde $90^{\circ}$ bükülerek hasır donatının içine geçirilmesi gerekmektedir. Verilen bu kurallar ve numunelerde uygulanan özellikler Tablo 2' de özetlenmiştir.

Tablo 2. DBYBHY 2007 'de [19] verilen minimum değerler ve numunelerde uygulanan özellikler

\begin{tabular}{|l|c|c|c|}
\hline & DBYBHY 2007 [19] & Seyrek ankraj & Sık ankraj \\
\hline Ankraj çubuklarının çapı $(\phi)$ & $12 \mathrm{~mm}$ & $6 \mathrm{~mm}$ & $6 \mathrm{~mm}$ \\
\hline Ankraj çubuklarının aralığı (s) & $300 \mathrm{~mm}$ & $300 \mathrm{~mm}$ & $100 \mathrm{~mm}$ \\
\hline Ankraj çubuklarının derinliği (l) & $12 \phi$ & $30 \mathrm{~mm}$ & $70 \mathrm{~mm}$ \\
\hline Duvar alanında bulunacak ankraj sayısı & 5 & 1 & 5 \\
\hline Hasır donatı ile dolgu duvar arasında pas payı & $20 \mathrm{~mm}$ & $20 \mathrm{~mm}$ & $20 \mathrm{~mm}$ \\
\hline Sıva tabakasının kalınlığı & $30 \mathrm{~mm}$ & $30 \mathrm{~mm}$ & $30 \mathrm{~mm}$ \\
\hline
\end{tabular}


Sık ankraj ile güçlendirilen numunede, üretilen numunenin ölçeği göz önüne alınarak $6 \mathrm{~mm}$ çapında ankraj çubuğu kullanılmıştır. Kolon ve kiriş yüzeylerinde matkap ile $100 \mathrm{~mm}$ aralıklarla 70 mm derinliğinde, dolgu duvar üzerinde ise Tablo 1'de gösterildiği gibi 5 adet ankraj deliği açılmıştır (Şekil 5).

Ankraj deliklerinin hava komprasörü ile iyice temizlenmesinin ardından çift bileşenli epoksi yardımıyla L şeklinde hazırlanan ankraj çubukları hasır donatının içerisine geçirilerek yerleştirilmiştir (Şekil 4). Hasır donatı ile dolgu duvar arasında DBYBHY 2007' de [19] öngörüldüğü şekilde $2 \mathrm{~cm}$ paspayı oluşacak şekilde düzenlenmiştir

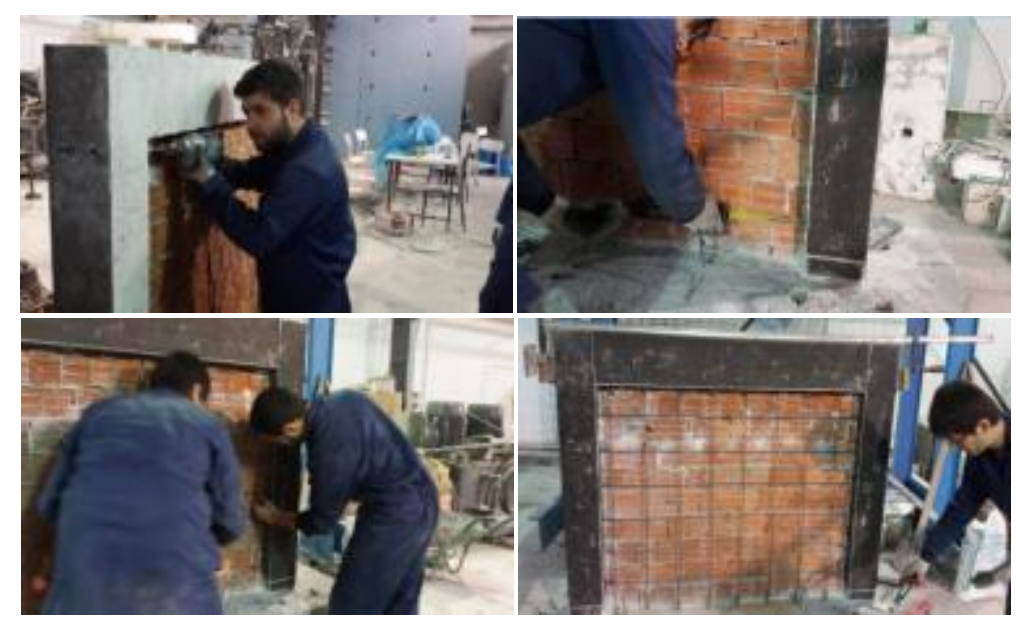

Şekil 4. Numune üzerinde hasır donatının ankraj çubuklarının epoksi yardımıyla yerleştirilmesi

Seyrek ankraj ile güçlendirilen numunede ise yetersiz aralıklar ve sıradan işçilikle uygulama yapılmıştır. Bu numunede ankraj çubuk çapı $6 \mathrm{~mm}$ olarak kullanılmıştır. Kolon ve kiriş yüzeylerinde ise matkap ile $300 \mathrm{~mm}$ aralıklarla $30 \mathrm{~mm}$ derinliğinde, dolgu duvar üzerinde ise Tablo 1' de gösterildiği şekilde 1 adet ankraj deliği açılmıştır. Ankraj deliklerinin hava komprasörü kullanılmaksızın özen gösterilmeden temizlenmesinin ardından çift bileşenli epoksi yardımıyla L şeklinde hazırlanan ankraj çubukları hasır donatının içerisine geçirilerek yerleştirilmiştir.

Hasır donatının yerleştirilmesinin ardından yüksek mukavemetli harç yardımıyla hasır donatının üzeri kapatılmıştır. Harç her iki numune içinde aynı özelliklerde oluşturulmuştur. Böylece kalıp işçiliğine gerek kalmadan yapılacak uygulamanın davranış üzerindeki etkinliği incelenmiştir. Harç karışımı DBYBHY 2007'de [19] verildiği şekilde 4 hacim kum, 1 hacim çimento, 1 hacim kireç kullanılarak hazırlanmıştır. Sıva tabakasının kalınlığı 30 mm olacak şekilde uygulanmıştır (Şekil 5).

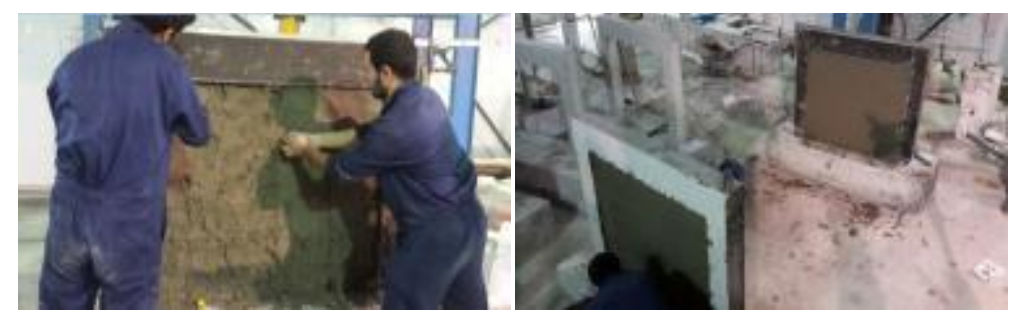

Şekil 5. Hasır donatı üzerine hazırlanan harç karışımının uygulanması

Numunelerin güçlendirilmesinin ardından harç karışımının mukavemetini kazanması için 28 günlük kür sürelerinin tamamlanması beklenmiştir. Deney sırasında gelişecek çatlakların gözlenebilmesi için deney elemanlarının dış yüzeyleri kireç ile badana yapılmıştır. 


\subsection{Yükleme Düzeneğinin Hazırlanması}

Numune deneylerinin gerçekleştirilebilmesi için hazırlanan yükleme düzeneği Şekil 6' da görülmektedir. Yük hücresinden sonra yerleştirilen mafsal ile çerçevenin ötelenmesinden sonrada yatay yükün çerçeveye dik olarak etkimesi sağlanmaktadır. Numunenin her iki taraftaki kiriş hizasına yerleştirilen çelik plakalar birleştirilerek reaksiyon duvarı üzerindeki düzeneğe bağlanmıştır. Bunun yanı sıra hidrolik kriko ünitesi yarı yarıya çıkarılarak, hem itme hem de çekme yüklemesi yapılabilmesine olanak sağlanmıştır.

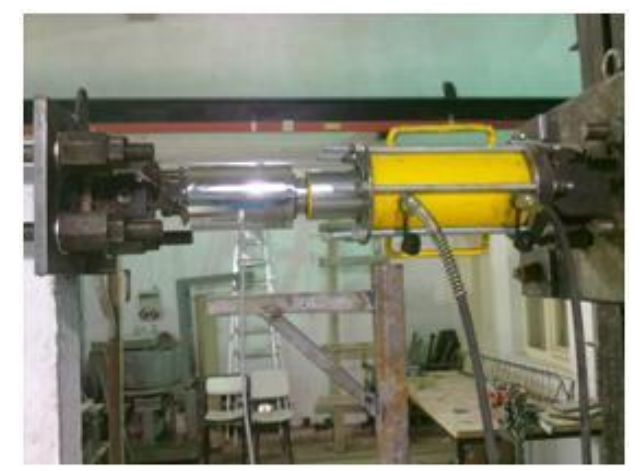

Şekil 6. Deney sırasında kullanılan yükleme düzeneği

Ölçümlerde yerdeğiştirme ölçerler kullanılmıştır. Yerleştirilen ölçüm cihazlarının konumları Şekil 7'de verilmiştir.

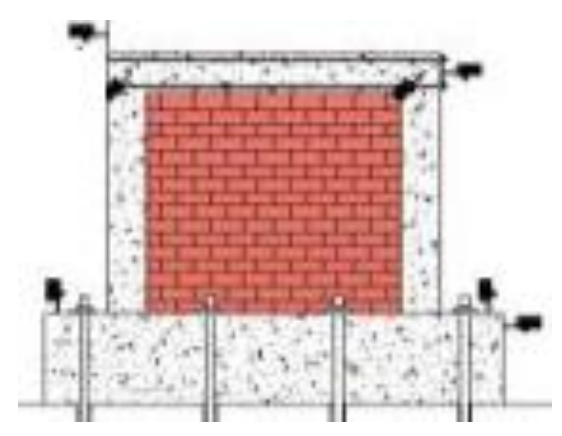

Şekil 7. Yerdeğiştirme ölçerlerin konumları

Deney sırasında yükleme düzlemine dik doğrultuda hareketin ortaya çıkmasını engellemek amaciyla numune kirişi üzerine kayar mesnet yerleştirilmiştir. Bunun için plastik tekerlekler kullanılmıştır (Şekil 8). Bu tekerler kuvvet doğrultusundaki hareketi engellememiştir.

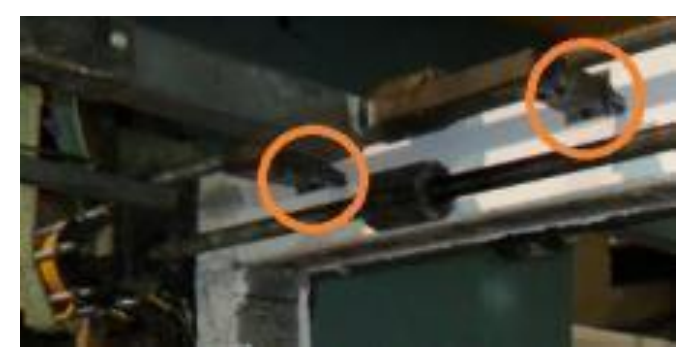

Şekil 8. Numuneye yerleştirilen kayar mesnetler 


\section{Bulgular ve Tartışma}

\subsection{Deney Sonuçları}

Üretilen tüm numuneler sirasıyla yükleme düzeneği altında itme ve çekme olarak yatay yüke tabi tutulmuştur. Deneyde numuneye etkiyen yatay yük itme ve çekme olarak her çevrimde $5 \mathrm{kN}$ arttırılarak uygulanmıştır. Deney yük kontrollü olarak yapılmıştır. Taşıma gücü yüküne ulaşıldıktan sonra deneye yer değiştirme kontrollü olarak devam edilmiştir. Deney sırasında oluşan hasarlar, her aşama için işaretlenmiştir. İtme ve çekme yüklemelerinin ayırt edilebilmesi için işaretlemelerde iki farklı renkte tebeşir kullanılmıştır.

\subsubsection{Yalın Numune (N-1) Deneyi}

N-1 deneyinde ulaşılan taşıma gücü yükü $50 \mathrm{kN}$ olarak elde edilmiş̧ir. İlk çatlama kolonda 15 kN'da oluşmuştur. Deney öncesi ve sonrası numuneye ait görünüm Şekil 9'da verilmiştir.
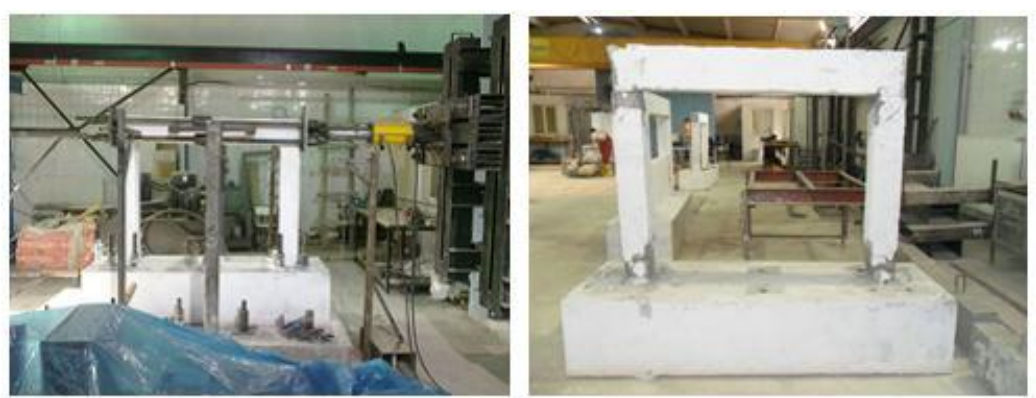

Şekil 9. N-1 deney öncesi ve sonrası görünümleri

Deney sonucunda elde edilen yatay yük- yer değiştirme grafiği Şekil 10'da verilmiştir.

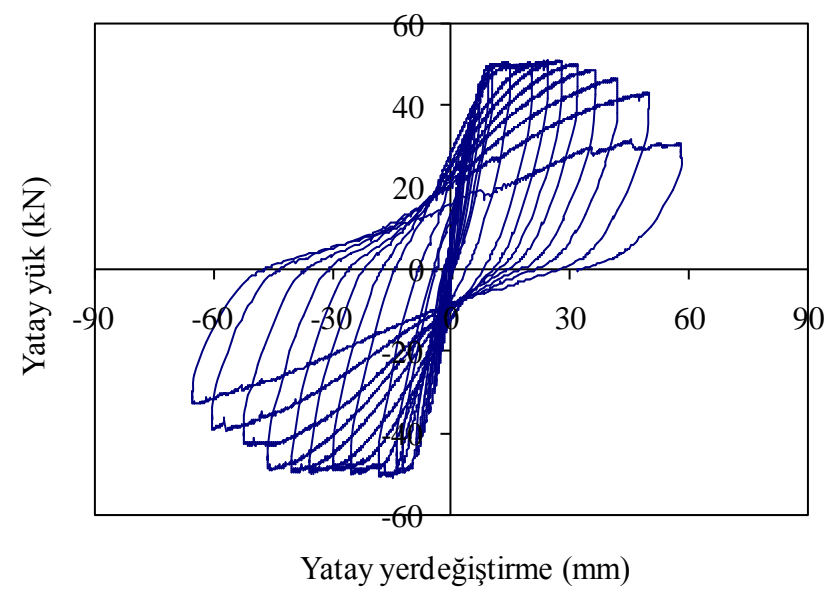

Şekil 10. N-1 yatay yük-yerdeğiştirme çevrimsel grafiği

\subsubsection{Tam Dolu Dolgu Duvar Örülü Numune (N-2) Deneyi}

N-2 numunesinde ilk çatlamalar dolgu duvarda $25 \mathrm{kN}$ 'da, kolonda ise $45 \mathrm{kN}$ 'da oluşmuştur. Numunenin taşıma gücü yükü $110 \mathrm{kN}$ ' a ulaşmıştır. Deney öncesi ve sonrası numuneye ait görünümleri Şekil 11' de verilmiştir. Duvarda oluşan hasar, X şeklinde ortaya çıkmıştır. Çatlakların genişlemesi ile duvar devrilerek yük taşıma yeteneğini kaybetmiştir. 


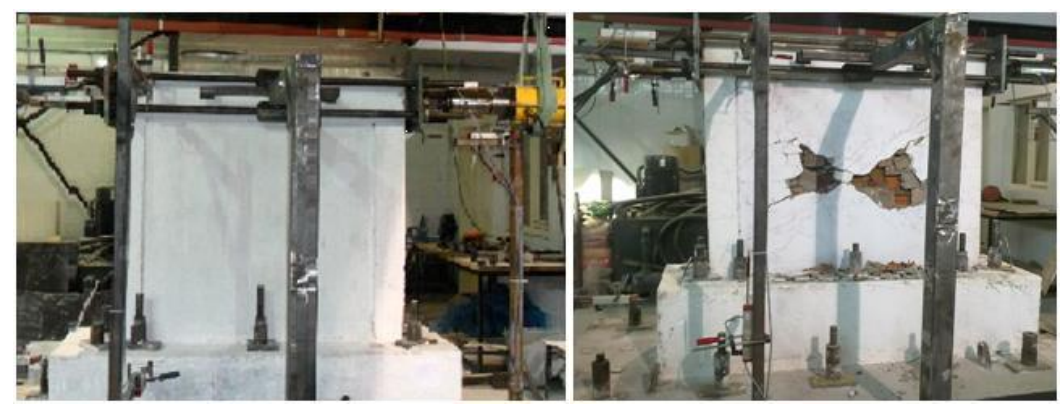

Şekil 11. N-2 deney öncesi ve sonrası görünümleri

Deney sonucunda elde edilen yatay yük- yer değiştirme grafiği Şekil 12' de verilmiştir.

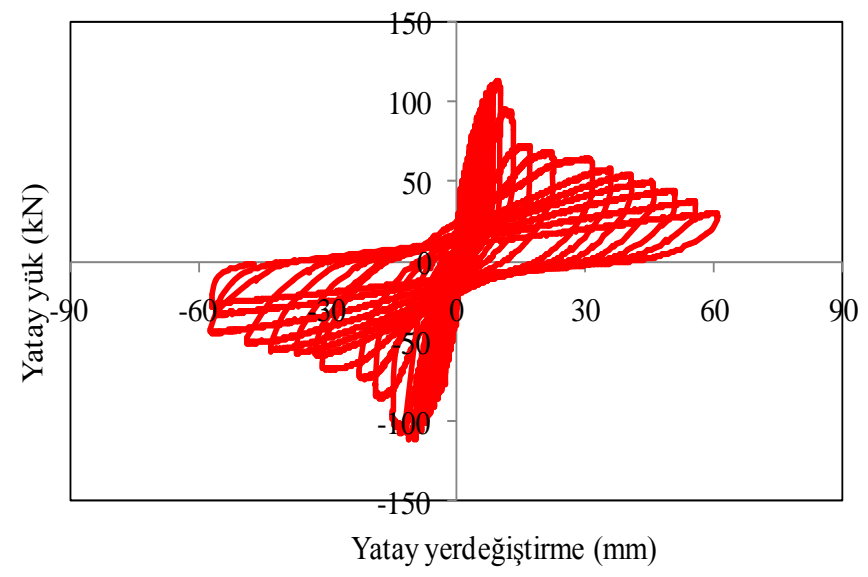

Şekil 12. N-2 yatay yük-yerdeğiştirme çevrimsel grafiği

\subsubsection{Seyrek Ankraj İle Güçlendirilen Numune (N-3) Deneyi}

N-3 numunesinde ilk çatlamalar kolonda $50 \mathrm{kN}$ 'da oluşmuştur. Duvar üzerindeki ilk eğik çatlak 80 kN'da oluşmuş ve numunenin taşıma gücü yükü $130 \mathrm{kN}$ ' a ulaşmıştır. Deney öncesi ve sonrası numuneye ait görünümleri Şekil 13 'te verilmiştir. Deney sonrasında güçlendirme uygulanan yüzeyde hasır donatı seviyelerinde kılcal çatlama gözlenirken, güçlendirme uygulanmayan yüzeyde dolgu duvar üzerinde X şeklinde çatlaklar oluşmuştur. Dolgu duvar elemanı bu X çatlaklarının genişlemesi ile güç tükenmesine ulaşmıştır. Dolgu duvar ve çerçeve ile güçlendirme yüzeyi arasında yeterli ankrajın bulunmaması nedeniyle tam bir aderans sağlanamamıştır. Deney sırasında güçlendirilen yüzeyin dolgu duvardan ayrılması ile hasar gelişimi ortaya çıkmıştır. 


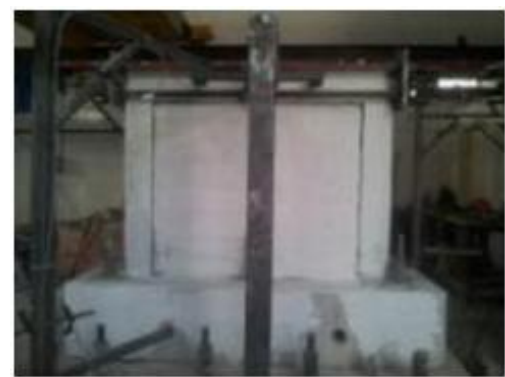

(a)

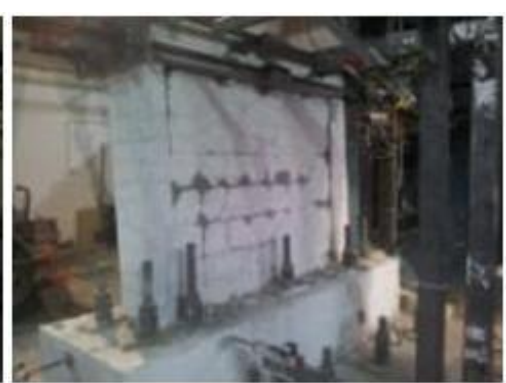

(b)

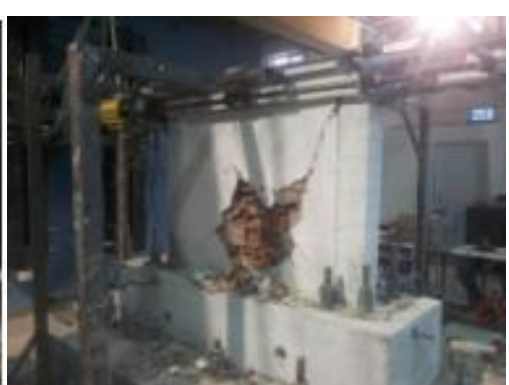

(c)

Şekil 13. N-3 deney numunesinin görünümü

(a) Deney öncesi

(b) Deney sonrası güçlendirme uygulanan yüzey

(c) Deney sonrası güçlendirme uygulanmayan yüzey

Deney sonucunda elde edilen yatay yük- yer değiştirme grafiği Şekil 14'te verilmiştir.

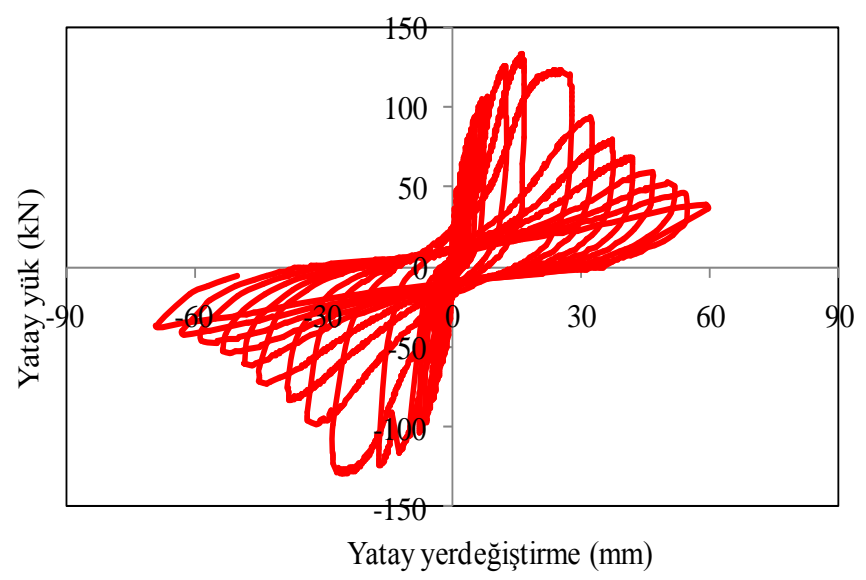

Şekil 14. N-3 yatay yük-yerdeğiştirme çevrimsel grafiği

\subsubsection{Sık Ankraj İle Güçlendirilen Numune (N-4) Deneyi}

N-4 numunesinde ilk çatlamalar kolonda $50 \mathrm{kN}$ 'da, dolgu duvarda ise $85 \mathrm{kN}$ 'da oluşmuştur. Numunenin taşıma gücü yükü $140 \mathrm{kN}$ ' a ulaşmıştır. Deney öncesi ve sonrası numuneye ait görünümleri Şekil $15^{\prime}$ te verilmiştir. Seyrek ankraj ile güçlendirilen numune hasarına benzer şekilde, bu numunede de güçlendirme uygulanan yüzeyde hasır donatı seviyelerinde kılcal çatlama gözlenirken, güçlendirme uygulanmayan yüzeyde dolgu duvar üzerinde $\mathrm{X}$ şeklinde çatlaklar oluşmuştur. Güçlendirme yüzeyi ile dolgu duvar ve çerçeve arasında ayrılma ancak dolgu duvarın ileri derecede hasara uğraması ile ortaya çıkmıştır. Hasarın ilerlemesi ile çerçeve üzerindeki bazı ankraj çubuklarının hasır donatıdan sıyrıldığı gözlenmiştir.

Deney sonucunda elde edilen yatay yük- yer değiştirme grafiği Şekil 16'da verilmiştir. 


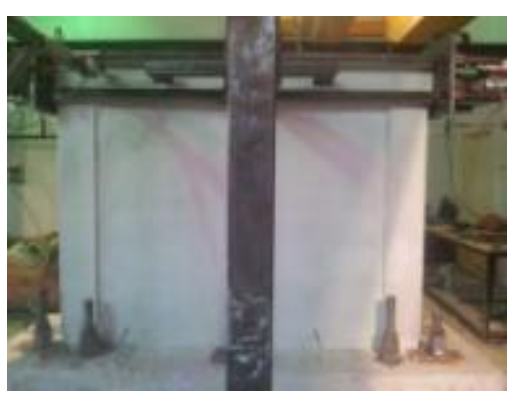

(a)

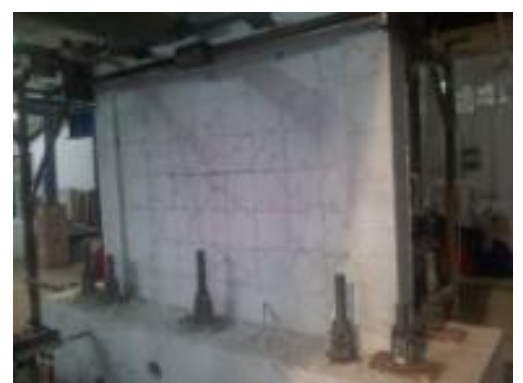

(b)

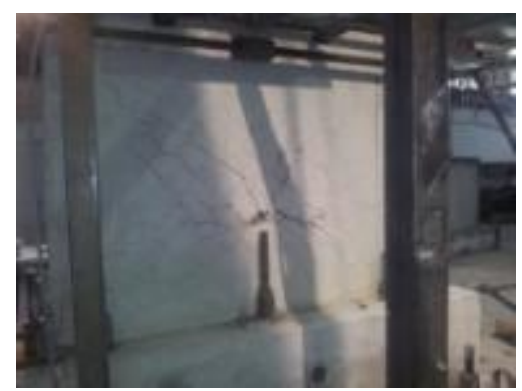

(c)

Şekil 15. N-4 deney numunesinin görünümü

(a) Deney öncesi

(b) Deney sonrası güçlendirme uygulanan yüzey

(c) Deney sonrası güçlendirme uygulanmayan yüzey

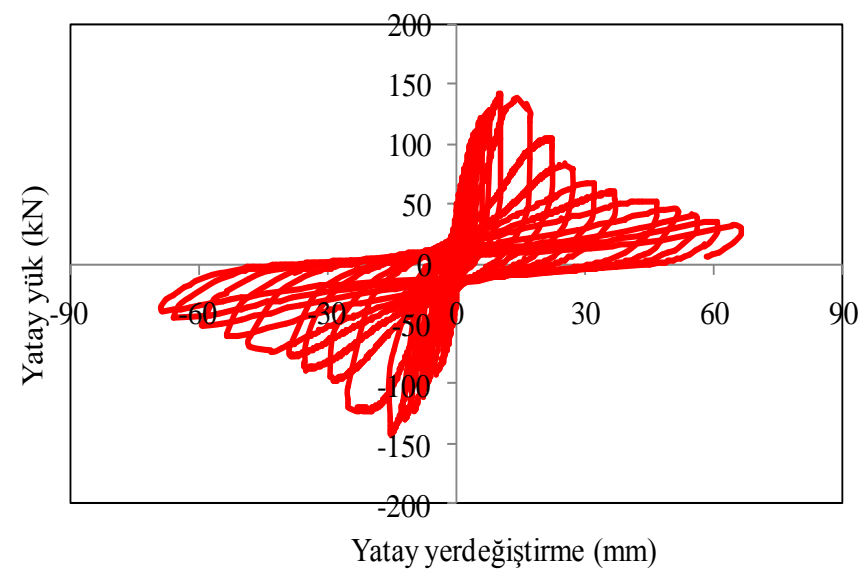

Şekil 16. N-4 yatay yük-yerdeğiştirme çevrimsel grafiğgi

\subsection{Deney Sonuçlarının Kıyaslanması}

Tüm deney sonuçlarından elde edilen yatay yük-yerdeğiştirme grafikleri Şekil 17' de, enerji tüketimiyerdeğiştirme grafikleri Şekil 18' de verilmiştir. Ayrıca kapasite değerleri tüm numuneler için karşılaştırmalı olarak Tablo 3 'te özetlenmiştir.

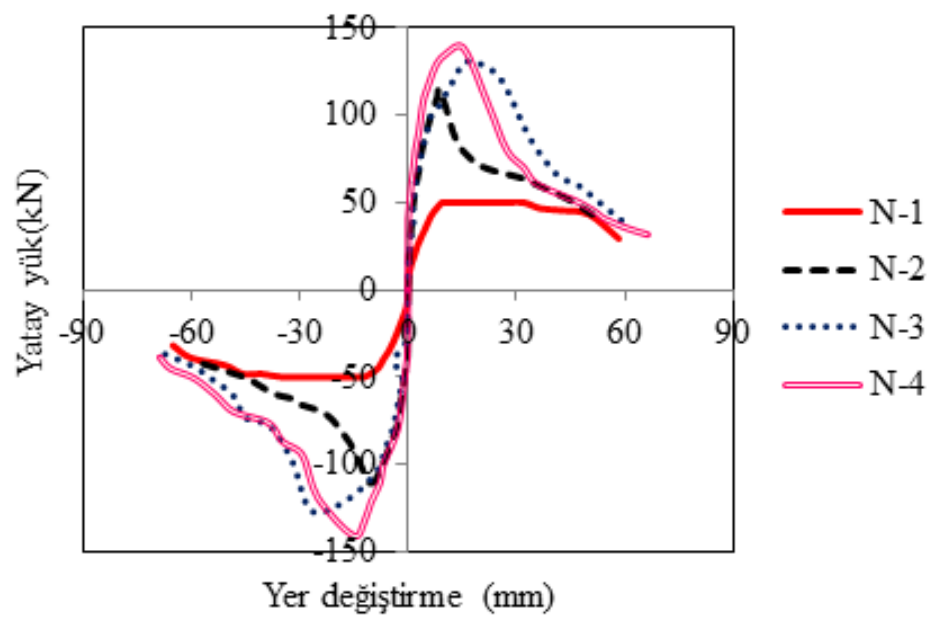

Şekil 17. Numunelerde elde edilen yatay yük-yerdeğiştirme grafiklerinin zarf eğrileri 


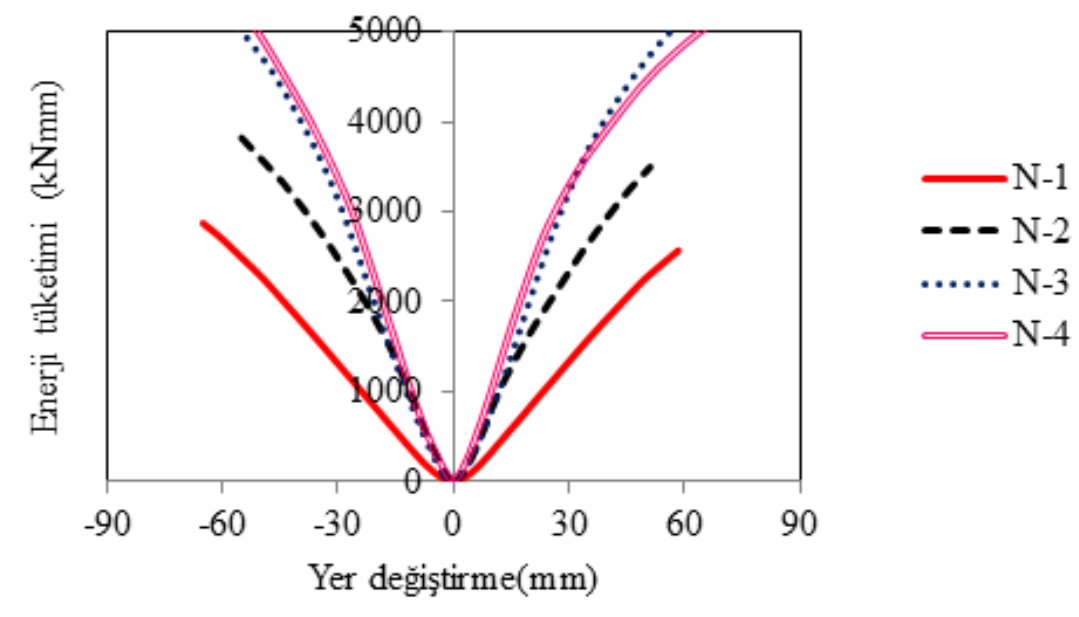

Şekil 18. Numunelerde elde edilen enerji tüketimi-yerdeğiştirme grafikleri

Tablo 3. Deney numunelerinin kapasite değerlerinin kıyaslanması

\begin{tabular}{|l|c|c|c|c|c|c|c|c|}
\hline \multirow{2}{*}{ Kapasite değeri } & \multicolumn{2}{|c|}{$\mathrm{N} 1$} & \multicolumn{2}{c|}{$\mathrm{N} 2$} & \multicolumn{2}{c|}{ N3 } & \multicolumn{2}{c|}{ N4 } \\
\cline { 2 - 9 } & İtme & Çekme & İtme & Çekme & İtme & Çekme & İtme & Çekme \\
\hline Yük $(\mathrm{kN})$ & 50 & 50 & 115 & 110 & 130 & 127 & 138 & 140 \\
\hline Enerji tüketme $(\mathrm{kNmm})$ & 2600 & 2800 & 3850 & 3900 & 5140 & 5600 & 5100 & 5900 \\
\hline
\end{tabular}

\section{Sonuçlar}

Dolgu duvarlı betonarme çerçevelerin hasır çelik donatılı özel sıva ile güçlendirilmesinin etkinliğinin incelenmesi amacıyla, 4 adet tek katlı, tek açıklıklı ve 1/3 ölçekli aynı yapısal özelliklere sahip betonarme çerçeve üretilmiştir. Bu numunelerden bir tanesi yalın olarak bırakılmıştır. Diğer üçünde açıklığın tamamı dolgu duvar ile örülmüştür. Tuğla dolgu duvarlı betonarme çerçevelerden iki tanesi, duvar yüzeyine uygulanan hasır donatı ile güçlendirilmiştir. Güçlendirilen iki numunede ankraj aralığ ve işçiliği değiştirilmiştir. Böylece yapılan çalışma ile dolgu duvarlı yapıların davranışa etkisi, güçlendirme yönteminin etkinliği, uygulamada karşılaşılan detay ve işçilik farklılıklarının davranışa etkisi gibi farklı parametrelerin değerlendirilmesi sağlanmıştır.

- Hem seyrek hem de sık ankraj ile güçlendirilen numunelerin, güçlendirilen yüzeyinde hasır donatı seviyelerinde kare ağ şeklinde kılcal çatlama gözlenirken, güçlendirme uygulanmayan yüzeyde dolgu duvar üzerinde X şeklinde çatlaklar gözlenmiştir.

- Seyrek ankraj ile güçlendirilen numunede dolgu duvar ve çerçeve ile güçlendirme yüzeyi arasında yeterli ankrajın bulunmaması nedeniyle tam bir aderans sağlanamamıştır. Deney sırasında güçlendirilen yüzeyin dolgu duvardan ayrılması ile hasar gelişimi ortaya çıkmıştır.

- S1k ankraj ile güçlendirilen numunede ise güçlendirme yüzeyi ile dolgu duvar ve çerçeve arasında ayrılma ancak dolgu duvarın ileri derecede hasara uğraması ile ortaya çıkmıştır. Hasarın ilerlemesi ile çerçeve üzerindeki bazı ankraj çubuklarının hasır donatıdan sıyrıldığı gözlenmiştir.

- Yanal yük taşıma kapasitesi yaklaşık olarak yalın numunede $50 \mathrm{kN}$, dolgu duvarlı numunede 110 $\mathrm{kN}$, seyrek ankraj ile yapılan güçlendirmede $130 \mathrm{kN}$ ve sık ankraj ile güçlendirmede $140 \mathrm{kN}$ olarak elde edilmiştir. Yanal yük taşıma kapasitesi açısından dolgu duvarlı numunede $\% 120$, seyrek ankraj ile yapılan güçlendirmede $\% 160$ ve sık ankraj ile güçlendirmede $\% 180$ yalın numuneye göre artış sağlanmıştır. 
- Enerji tüketme kapasiteleri ise yaklaşık olarak yalın numunede $2800 \mathrm{kNmm}$, dolgu duvarlı numunede $3900 \mathrm{kNmm}$, seyrek ankraj ile yapılan güçlendirmede $5600 \mathrm{kNmm}$ ve sık ankraj ile güçlendirmede $5900 \mathrm{kNmm}$ olarak elde edilmiştir. Enerji tüketme kapasiteleri açısından dolgu duvarlı numunede $\% 30$, seyrek ankraj ile yapılan güçlendirmede $\% 100$ ve sik ankraj ile güçlendirmede $\% 110$ yalın numuneye göre artış sağlanmıştır.

- Yapılan güçlendirme ile numunenin yanal yük taşıma kapasitesinde ve enerji tüketme kapasitesinde artış meydana gelmiştir. Bu artış sık ankrajda daha fazla olarak gözlenmiştir.

- Yapılan deneylerde güçlendirmenin dolgu duvarın tek tarafına uygulanması ile güçlendirilmeyen yüzeyde dolgu duvar hasarı $\mathrm{X}$ şeklinde ilerleyerek güçlendirmenin devreden çıkmasına neden olmuştur. $\mathrm{Bu}$ nedenle güçlendirme işleminin tek taraflı yerine dolgu duvarın iki tarafina da uygulanmasının çok daha etkili olacağı düşünülmektedir.

\section{Teşekkür}

Bu çalışma Tübitak 2209 projesi ile desteklenmiştir. Sağladığı destek için Tübitak'a teşekkürü bir borç biliriz.

\section{Kaynaklar}

1. Acun B., Sucuoğlu H. 2005. Tuğla Dolgu Duvarlı Çerçevelerin Hasır Donatı İle Güçlendirilmesi, Deprem Sempozyumu, 23-25 Mart, Kocaeli.

2. Ökten S. 2013. Lifli Çimento Esaslı Kompozitlerle Güçlendirilmiş Dolgu Duvarlı Betonarme Çerçevelerin Deneysel İncelenmesi, Doktora Tezi, İstanbul Teknik Üniversitesi, Fen Bilimleri Enstitüsü, İstanbul.

3. Özkan C. 2012. Çimento Esaslı Kompozitlerle Güçlendirilen Dolgu Duvarlı Betonarme Çerçevelerin Tersinir Tekrarlı Yükler Altında Davranışı, Yüksek Lisans Tezi, İstanbul Teknik Üniversitesi, Fen Bilimleri Enstitüsü, İstanbul.

4. Akın E. 2011. Strengthening of Brick Infilled RC Frames with CFRP Reinforcement-General Principles, PhD Thesis, Middle East Technical University, The Graduate School of Natural and Applied Sciences, Ankara.

5. Baştemir İ. 2009. Büyük Atalet Kuvvetleri Etkisindeki Bölme Duvarlı Betonarme Çerçevelerin Lifli Polimerler İle Güçlendirilmesi, Yüksek Lisans Tezi, İstanbul Teknik Üniversitesi, Fen Bilimleri Enstitüsü, İstanbul.

6. Zhu J.T., Wang X.L., Xu Z.D., Weng C.H. 2011. Experimental Study on Seismic Behavior of RC Frames Strengthened with CFRP Sheets, Composite Structures, 93: 1595-1603.

7. Yüksel E., Yalçın C. 2008. Benzeşik Dinamik Deney Tekniği Kullanılarak Karbon Liflerle Güçlendirilmiş Bölme Duvarlı Betonarme Çerçevelerin İncelenmesi, Tübitak 106M050 numaralı proje sonuç raporu, Ankara.

8. Binici B., Ozcebe G., Ozcelik R. 2007. Analysis and Design of FRP Composites for Seismic Retrofit of Infill Walls in Reinforced Concrete Frames, Composites: Part B, 38: 575-583.

9. Baran M., Canbay E., Tankut T. 2010. Beton Panellerle Güçlendirme - Kuramsal Yaklaşım, İMO Teknik Dergi, 324: 4959-4978.

10.Sezer R., Akın A. 2011. Dolgu Duvarları Önüretimli Beton Panellerle Güçlendirilmiş Betonarme Çerçevelerin Deprem Davranışının İncelenmesi, e-Journal of New World Sciences Academy, 6 (4): $127-1145$.

11.Arslan G. 2009. Strengthening of Reinforced Concrete Frames by Custom Shaped High Strength Concrete Masonry Blocks, MSc thesis, Middle East Technical University, The Graduate School of Natural and Applied Sciences, Ankara. 
12.Anil O., Altin S. 2007. Experimental Study on Reinforced Concrete Partially Infilled Frames. Engineering Structures, 29: 449-460.

13.Ünal A., Korkmaz H.H., Kaltakcı M.Y., Kamanlı M., Bahadır F., Balık F.S. 2013. Deprem Dayanımı Yetersiz Betonarme Çerçevelerin Düzlem Dışı Perde Duvar İle Güçlendirilmesi, 2. Türkiye Deprem Mühendisliği ve Sismoloji Konferans1, 25-27 Eylül, Hatay.

14.Yılmaz Ü., Arslan H., Kaltakcı Y. 2010. Betonarme Dış Perde Duvarla Güçlendirilmiş Çerçevelerin Dayanım Parametrelerinin Deneysel Ve Analitik Yöntemlerle İrdelenmesi, Tübav Bilim Dergisi, 3 (1): 11-22.

15.Özdöner N. 2011. Betonarme Binaların Deprem Güvenliğinin, Bina Dışından Uygulanan Betonarme Prefabrik Paneller İle Arttırılması, Doktora Tezi, Selçuk Üniversitesi, Fen Bilimleri Enstitüsü, Konya.

16.Kılıç A. 2012. Betonarme Çerçeveli Yapılarda Dolgu Duvarların Güçlendirilmesi, Selçuk Üniversitesi Fen Bilimleri Enstitüsü, Yüksek Lisans Tezi, Konya.

17.Özdemir H. 2008. Dolgu Duvarlı Çerçevelerin Hasır Çelik Donatılı Sıva İle Güçlendirilmesi, İstanbul Teknik Üniversitesi, Fen Bilimleri Enstitüsü, Doktora Tezi, İstanbul.

18.Özdemir H., Eren İ. 2009. Bölme Duvarının Ve Bölme Duvar Güçlendirilmesinin Çerçeve Davranışına Etkisi, İTÜ Dergisi/d, 8 (6): 133-145.

19.Anonim 2007. Deprem Bölgelerinde Yapılacak Binalar Hakkında Yönetmelik (DBYBHY). Bayındırlık ve İskan Bakanlığı (Mülga), Ankara.

Geliş Tarihi: 11.07.2014

Kabul Tarihi: 23.12. 2014 